\title{
Mating behaviour of the lizard Ameiva ameiva in Brazil
}

\author{
RENAN AUGUSTO RAMALHO ${ }^{1,2, *}$, LUIS MIGUEL LOBO ${ }^{1}$, SERENA NAJARA MIGLIORE ${ }^{1,3}$ \& SELMA \\ MARIA DE ALMEIDA-SANTOS 1,3
}

${ }^{1}$ Laboratório de Ecologia e Evolução, Instituto Butantan - Avenida Vital Brazil, 1500, Butantã, 05503-900, São Paulo, SP, Brazil ${ }^{2}$ Universidade Nove de Julho, Campus Memorial - Avenida Dr. Adolpho Pinto, 109, Barra Funda, 01156-050, São Paulo, SP, Brazil ${ }^{3}$ Faculdade de Medicina Veterinária e Zootecnia, Universidade de São Paulo, Departamento de Cirurgia - Avenida Orlando Marques de Paiva, Cidade Universitária, 8705508-000, São Paulo, SP, Brazil

*Corresponding author e-mail: renan.ramalho@esib.butantan.gov.br

\begin{abstract}
The courtship and copulation behaviours of the lizard Ameiva ameiva is described from field observations made at various locations in Brazil. In males, the main behaviours observed during one observation of courtship were head bobbing, circling and walking over the females, rubbing his body against the female, mounting, and dismounting. Females generally remain passive throughout courtship. The reproductive behaviour of $A$. ameiva resembles that of other teiids, however males exhibit some behavioural peculiarities, such as circling the female to restrict her movements, no cloacal rubbing against the ground, and no biting during copulation.
\end{abstract}

\section{INTRODUCTION}

$T^{1}$ he most common mating system reported for lizards, including non-territorial lizards such as teiids, is polygyny, in which males move over wide areas actively searching for multiple mates (sequential polygyny; Pianka \& Vitt, 2003; Vitt, 2003). In these non-territorial species, the mere presence of a male is insufficient for mating to occur, instead females select males based on the size and shape of their bodies (Pianka \& Vitt, 2003).

Courtship and copulation in lizards involve a series of ritualised behaviours (Vitt, 1983; Costa et al., 2010; Gogliath et al., 2010; Ribeiro et al., 2011). Examples of these behaviours in teiid lizards include chase, cloacal rubbing and head bobbing (Carpenter, 1960, 1962; Quesnel, 1978; Costa et al., 2013; Sales \& Freire, 2021). Sexual size dimorphism, sexual dichromatism, and behavioural displays are intricately linked to courtship and copulation and are fundamental to sexual selection (Noble \& Bradley, 1933; Vitt, 1983; Censky, 1997).

Copulation in teiid lizards may involve some behaviours performed by the male, such as biting the female's flank or pelvic region and posture patterns during the intromission phase (Carpenter, 1960; Crews, 1987; Mahrdt, 1976; Ribeiro et al., 2011; Alfonso \& Torres, 2012, Sales \& Freire, 2021). Mate guarding after copulation seems to be common in teiid lizards, which reduces the opportunity for female to mate with other males. The occurrence of mate guarding lasting for days indicates that male-female associations may be longer than previously thought, even in lizards practising sequential polygyny (Quesnel, 1978; Anderson \& Vitt, 1990; Censky, 1995; Colli et al., 1997; Zaldívar-Rae et al., 2008).

The teiid lizard Ameiva ameiva is widely distributed in Brazil, inhabiting areas of the Caatinga, Amazon, Cerrado, and Atlantic Forest, where it exhibits diurnal and terrestrial habits and forages actively in open areas with high solar exposure (Vitt, 1982; Magnusson, 1987; Colli, 1991; Vitt \& Colli, 1994; Rocha, 2008). Males grow larger than females (Rocha, 2008); this may relate to sexual selection (Anderson \& Vitt, 1990). Despite advances in behavioural ecology, descriptions of the reproductive behaviour of teiid lizards remain scarce (Censky, 1995; Zaldívar-Rae \& Drummond, 2007; Sales \& Freire, 2021). Here we describe the courtship and mating behaviour of free-ranging $A$. ameiva.

Table 1. Location and date of the available records of courtship and copulation of Ameiva ameiva in Brazil

\begin{tabular}{|c|c|c|c|c|}
\hline Location & Date & Season & Source & Observed event \\
\hline Ribeirão Preto, São Paulo state & March 2005 & Summer & This study & Mating \\
\hline Parque Pedra da Cebola, Vitória, Espírito Santo state & 7th October 2012 & Spring & This study & Mating \\
\hline Cariacica, Espírito Santo state & 3rd December 2018 & Spring & This study & Mating \\
\hline Vale do Capão, Palmeiras, Bahia state & 17th December 2018 & Spring & This study & Mating \\
\hline Cantá, Roraima state & 29th May 2019 & Autumn & This study & Mating \\
\hline Sítio Córrego do Areião, Brodowski, São Paulo state & 10th January 2020 & Summer & This study & Courtship and mating \\
\hline Parque Nacional da Serra do Cipó, Minas Gerais state & 22nd October 2001 & Spring & Manata \& Nascimento (2005) & Courtship \\
\hline Tabajara, Inhapim, Minas Gerais state & 12nd March 2009 & Summer & Costa et al. (2010) & Courtship \\
\hline
\end{tabular}



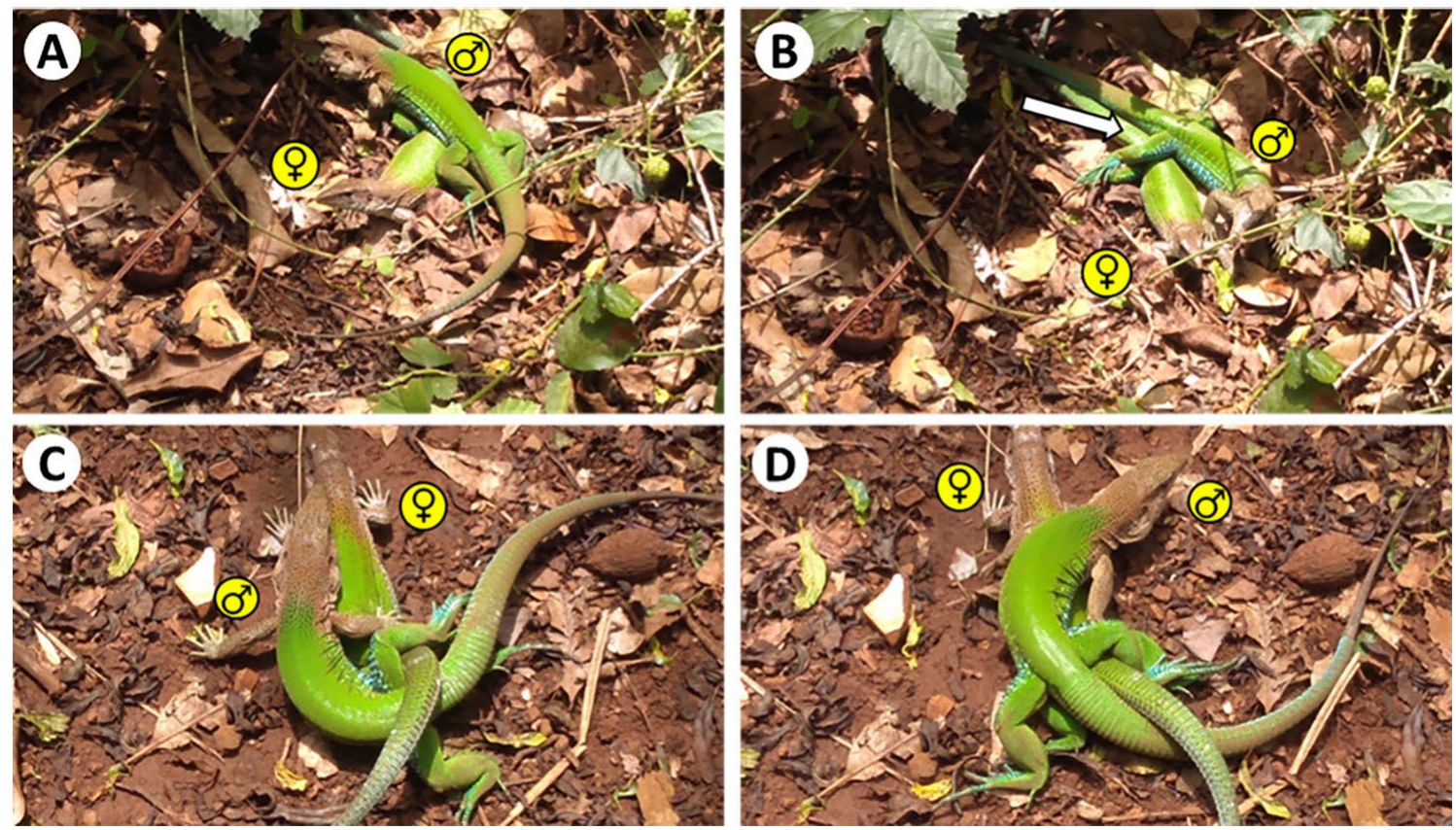

Figure 1. Courtship behaviour and position shift during copulation of the lizard Ameiva ameiva observed in Brodowski, São Paulo, south-eastern Brazil- A. Male circling the female and moving over the female's body at the base of the tail, B. Male rubbing his cloacal region over the base of the female's tail (arrow), C. Initial position during copulation, D. The male shifted position during copulation, moving over the female's body as she gradually lowers her tail

\section{MATERIALS \& METHODS}

We described courtship and copulation behaviours based on six fortuitous encounters videotaped by lay people between 2005-2020 at different locations in Brazil (Table 1). The description of the behavioural repertoire is based on Quesnel (1978). In each observation, we assumed that the largest individuals were males until the sex of each individual became evident during copulation, which refers to the moment the female arches her tail and male positions his cloaca in opposition to hers so that the intromission of the hemipenis can occur. To view one example of the courtship and copulation of $A$. ameiva watch our video (BHS, 2021).

\section{RESULTS}

We identified four distinct phases during courtship behaviour, which can occur successively or alternately: (1) approach on a spiral route, (2) circular movements around the female, (3) body contact, and (4) rubbing against the female's body. The complete courtship and mating sequence was recorded only once. In the other observations, the couples were either at the end of courtship or copulating when they were found (Table 1). Therefore, the description of the entire courtship behaviour was based on a single observation.

The male began the courtship by approaching the female in short spurts followed by head-bobbing displays. This sequence resulted in a direct approach, with the male continually circling and moving over the female's body at the base of the tail (Fig. 1A). At this time, the male rubbed his cloacal region over the female's tail base (Fig. 1B). The male then stopped courting the female, and both individuals foraged for $50 \mathrm{~s}$. The courtship was then resumed, with the male again circling the female. However, the female, which had previously remained static, started to move over the male's body to continue foraging. To restrain the female and regain her attention, the male placed his left forelimb over the female's pectoral girdle and rubbed the side of his body against hers. The male mounted and dismounted the female three times while rubbing his cloacal region against her body until she became receptive. The female then arched the tail base, and the male placed his tail under the female so that both cloacae were opposed. We could neither see the eversion of the hemipenis nor its insertion into the cloaca. The complete courtship sequence lasted about $270 \mathrm{~s}$. The tongue-flicking rate was high during courtship.

We were unable to identify the exact position of the individuals when copulations began. Although some body adjustments occurred, males and females remained immobile for most of the copulation. The males positioned themselves parallel to the females and placed their right fore- and hind limbs over the females' pelvic girdle and tail, respectively, thus resting on their left fore- and hind limbs. Moreover, males placed their tails under females' tails to bring their cloacae into close apposition (Fig. 1C). On some occasions, males shifted position during copulation, placing their bodies over females' bodies as they gradually lowered their tails (Fig. 1D). After copulation, the couple remained close to each other. Males resumed courtship behaviour by performing head-bobbing displays after each step forward.

One of the copulations occurred near an underground shelter. A female was seen leaving the shelter and being pursued by a male (Fig. 2A). After reaching the female, the male immediately mounted her and rubbed his ventral and cloacal regions on her back. This behaviour was followed by copulation (Fig. 2B). In one of the videos, we observed a third individual next to a mating pair. This individual approached the female after the copulation ended but the female 

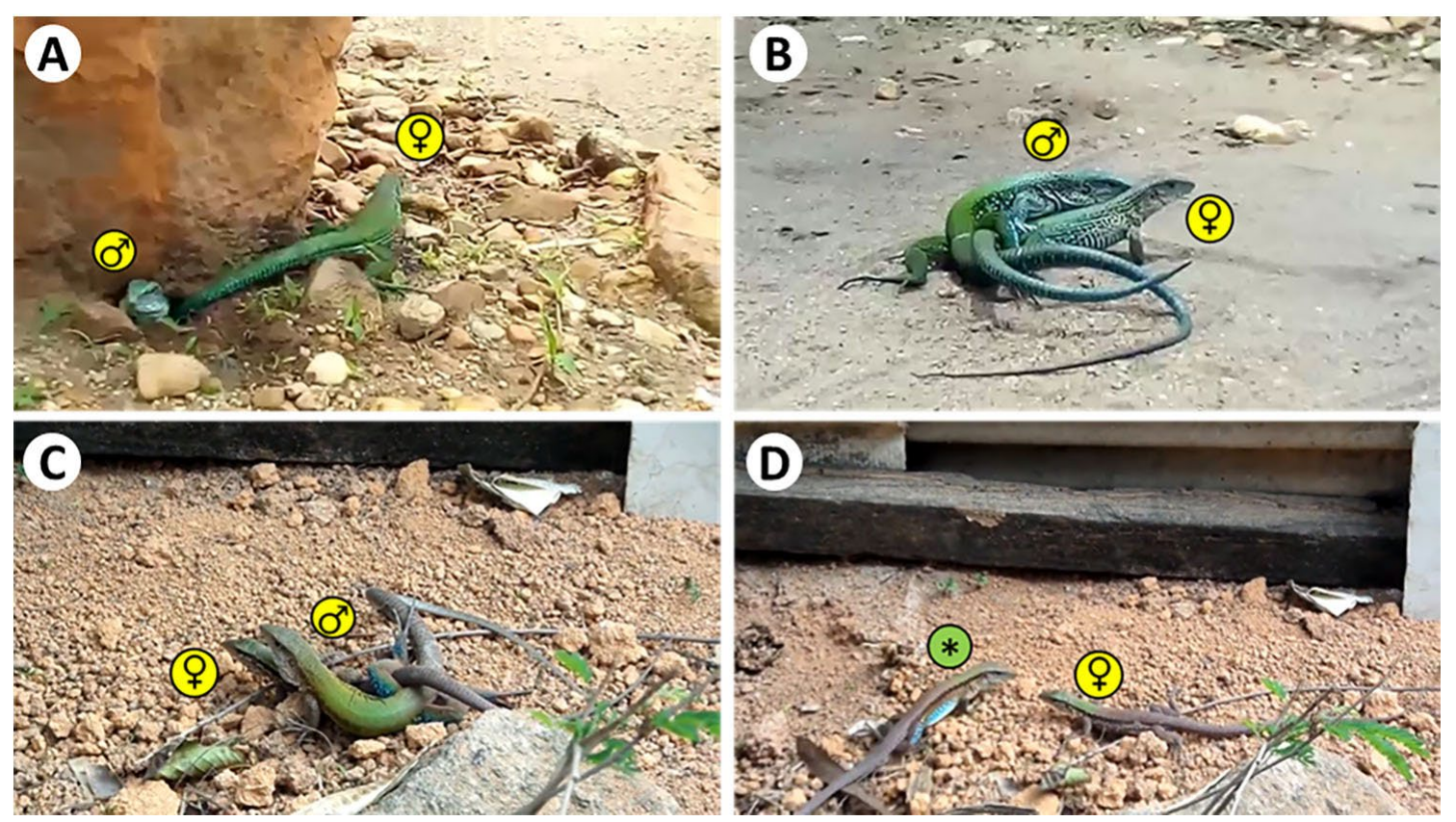

Figure 2. Copulation of the lizard Ameiva ameiva observed in Vale do Capão, Bahia, north-eastern Brazil (A, B), and Cariacica, Espírito Santo, south-eastern Brazil (C, D) - A. Female leaving an underground shelter while being pursued by a male, B. Copulation occurred immediately after the couple left the underground shelter (courtship behaviour probably occurred within the shelter), C. Male and a female copulating, D. A second individual $\left({ }^{*}\right)$ approaches the female after the copulation ended

quickly moved away after noticing the approach (Fig. 2C, D). Copulations lasted 22-164 s (mean $=94.5 \mathrm{~s}$ ). All observations were made during the daytime, and no aggressive behaviour was noticed.

\section{DISCUSSION}

The phases of the courtship behaviour of $A$. ameiva are in general similar to those of other lizard species, including other Ameiva (Quesnel, 1978; Manata \& Nascimento, 2005). In $A$. ameiva, the movements performed by males seem to go unnoticed by females. However, this apparent disinterest may indicate a positive response from the female and that she is tolerating his presence (Quesnel, 1978). The female passivity seems to be important for a successful approach and may be caused by the circular movements performed by the male. By circling the female, a courting male may restrict her movements (thus allowing body contact to occur) and suppress biting behaviours during copulation that have been reported in other teiids (e.g., Carpenter, 1962; Anderson \& Vitt, 1990; Zaldívar-Rae \& Drummond, 2007; Ribeiro et al., 2011; Alfonso \& Torres, 2012; Sales \& Freire, 2021), but have not been observed in A. ameiva (Manata \& Nascimento, 2005; this study) and other congeners (Quesnel, 1978). Moreover, cloacal rubbing against the ground, a behaviour already reported in male teiids (Carpenter, 1962; Sales \& Freire, 2021), was not observed.

The duration of courtship is variable in teiid lizards. Male Pholidoscelis auberi spend about 32 minutes pursuing and courting females (Alfonso \& Torres, 2012), while male Ameivula ocellifera court females for 0.8-121 minutes (Sales \& Freire, 2021). Costa et al. (2013) reported that a male Kentropyx calcarata stayed about 13 minutes close to a female before copulating. However, these authors observed no visual signalling between the specimens or any other behaviours reported here, such as head-bobbing displays, circular movements or cloacal rubbing over the female's body. The duration and number of repetitions of each courtship phase are variable (Quesnel, 1978).

The male position of $A$. ameiva during the intromission phase of copulation is similar to other teiid lizards that do not usually follow the arched posture pattern and bites during this phase (Quesnel, 1978; Censky, 1995; Costa et al., 2013). On the other hand, some male teiids from smaller species adopt the arched pattern, biting the female's pelvic region close to her hind limbs, in a ring shape that Crews (1987) called the 'doughnut posture' (Carpenter, 1962; Mahrdt, 1976; Anderson \& Vitt, 1990; Ribeiro et al., 2011; Alfonso \& Torres, 2012, Sales \& Freire, 2021).

In lizards, copulation is often interpreted as an isolated event. However, some records of multiple copulations in a short period suggest that copulation may be a serial event (Quesnel, 1978). Mate guarding has been observed in Ameiva (Quesnel, 1978; Manata \& Nascimento, 2005) and several teiids, such as Aspidoscelis (Anderson \& Vitt, 1990; Zaldívar-Rae \& Drummond, 2007; Zaldívar-Rae et al., 2008; Ancona et al., 2010), Pholidoscelis (Censky, 1995), and Ameivula (Ribeiro et al., 2011 ; Sales \& Freire, 2021). Male lizards can spend days guarding females. During this period, they copulate several times and chase away other males that try to approach the females (Censky, 1995, 1997; ZaldivarRae \& Drummond, 2007). By guarding the female as much as possible, males decrease the opportunity for rival males to access the female, which may increase their reproductive success (Bull, 2000; Ribeiro et al., 2011; Sales \& Freire, 2021). However, this behaviour is not always successful (Olsson et al., 1996). Our observation that the larger male moved away from the female shortly after copulation is similar to 
the observation of Sales \& Freire (2021) in which a male Ameivula ocellifera moved away and did not return to guard the female in the burrow that she had entered shortly after copulation, even though mate guarding or guarding of the female's burrow seems widespread in teiids (Quesnel, 1978; Censky, 1995, 1997; Alfonso \& Torres, 2012; Sales \& Freire, 2021).

Reproductive behaviour in $A$. ameiva occurs during both the spring-summer (rainy season) and the autumn (dry season) and varies geographically. It is continuous or extended in the Amazon forest, Caatinga, and the restingas of the Atlantic Forest but is more seasonal in the Cerrado and Amazonian savannas (Vitt \& Colli, 1994; Rocha, 2008). In summer in the Atlantic Forest, Costa et al. (2010) described courtship behaviour and attempted copulation between an adult male and a dead conspecific female that had six oviductal eggs. However, the size of these eggs resembles that of enlarged vitellogenic follicles (R.A. Ramalho, unpublished data) suggesting that the dead female was in late vitellogenesis.

Our observations show that $A$. ameiva shares some aspects of courtship and copulation behaviour with other teiids. However, the species exhibits some peculiarities, such as performing circular movements around the female to restrict her movements but does not engage in cloacal rubbing against the ground or biting during copulation. Further studies could focus on the dynamics of other reproductive strategies in A. ameiva, such as reproductive cycle and sperm storage, and relate them to interactions between males and females during and after the mating season.

\section{ACKNOWLEDGEMENTS}

We thank Alexandre Gois, Jorge Calazans, Luiz Antonio Rufato, Michael Siernandes, Willyam Belo de Oliveira, and the Cineryna-TV staff for providing us with the video recordings used in this work, and Henrique B. Braz for the translation. This study was funded by Conselho Nacional de Desenvolvimento Científico e Tecnológico (CNPq) (process no. $135518 / 2020-2$ ) for Ramalho, R.A.

\section{REFERENCES}

Alfonso, Y.U. \& Torres, J. (2012). Courtship Behavior in the Cuban Ameiva (Ameiva auberi ustulata, Squamata: Teiidae) from the Siboney-Jutici Ecological Reserve in Eastern Cuba. Reptiles and Amphibians 19: 85-89.

Ancona, S., Drummond, H. \& Zaldívar-Rae, J. (2010). Male whiptail lizards adjust energetically costly mate guarding to male-male competition and female reproductive value. Animal Behaviour 79: 75-82.

Anderson, R.A. \& Vitt, L.J. (1990). Sexual selection versus alternative causes of sexual dimorphism in teiid lizards. Oecologia 84: 145-157.

BHS Video (2021). Mating behaviour of the Ameiva ameiva lizard in Brazil. https://youtu.be/9qGOh35W5qw

Bull, C.M. (2000). Monogamy in lizards. Behavioural Processes 51: 7-20.

Carpenter, C.C. (1960). Aggressive behaviour and social dominance in the six-lined racerunner (Cnemidophorus sexlineatus). Animal Behaviour 8: 61-66.

Carpenter, C.C. (1962). Patterns of behavior in two Oklahoma lizards. American Midland Naturalist 7: 132-151.

Carpenter, C.C. (1977). The aggressive displays of three species of South American iguanid lizards of the genus Tropidurus. Herpetologica 33: 285-289.

Censky, E.J. (1995). Mating strategy and reproductive success in the teiid lizard, Ameiva plei. Behaviour 132: 529-557.

Censky, E.J. (1997). Female mate choice in the non-territorial lizard Ameiva plei (Teiidae). Behavioral Ecology and Sociobiology 40: 221-225.

Colli, G.R. (1991). Reproductive ecology of Ameiva ameiva (Sauria, Teiidae) in the Cerrado of central Brazil. Copeia 1991: 1002-1012.

Colli, G.R., Peres Jr, A.K. \& Zatz, M.G. (1997). Foraging mode and reproductive seasonality in tropical lizards. Journal of Herpetology 31: 490-499.

Costa, H.C., Drummond, L.O., Tonini, J.F.R. \& Zaldívar-Rae, J. (2013). Kentropyx calcarata (Squamata: Teiidae): Mating behavior in the wild. North-Western Journal of Zoology 9: 198-200.

Costa, H.C., Silva, E.T., Campos, P.S., Oliveira, M.D.C., Nunes, A.V. \& Santos, P.D.S. (2010). The Corpse Bride: A case of Davian behaviour in the Green Ameiva (Ameiva ameiva) in southeastern Brazil. Herpetology Notes 3: 79-83.

Crews, D. (1987). Courtship in unisexual lizards: A Model for Brain Evolution. Scientific American 257: 116-121.

Evans, L.T. (1938). Courtship behavior and sexual selection of Anolis. Journal of Comparative Psychology 26: 475-497.

Gogliath, M., Ribeiro, L.B. \& Freire, E.M.X. (2010). Forced copulation attempt in the blue-tailed Lizard, Micrablepharus maximiliani (Reinhardt \& Luetken, 1862) (Squamata, Gymnophthalmidae) in the Caatinga of northeastern Brazil. Biota Neotropica 10: 347-350.

Kelso, E.C. \& Verrell, P.A. (2002). Do male veiled chameleons, Chamaeleo calyptratus, adjust their courtship displays in response to female reproductive status? Ethology 108: 495-512.

Lima, A.F.B. \& Sousa, B.M. (2006). Court and copulation behaviors of Enyalius perditus Jackson, 1978 (Squamata, Leiosauridae) in captivity conditions. Revista Brasileira de Zoociências 8:193-197.

Magnusson, W.E. (1987). Reproductive cycles of teiid lizards in Amazonian savanna. Journal of Herpetology 21: 307-316.

Mahrdt, C.R. (1976). Courtship and copulatory behavior of Cnemidophorus tigris tigris (Sauria: Teiidae). The Southwestern Naturalist 21: 252-254.

Manata, F.P. \& Nascimento, L. B. (2005). Ameiva ameiva (Calango Verde). Courtship Behaviour. Herpetological Review 36: 62.

Noble, G.K. \& Bradley, H.T. (1933). The mating behavior of lizards; its bearing on the theory of sexual selection. Annals of the New York Academy of Sciences 35: 25-100.

Olsson, M., Gullberg, A. \& Tegelström, H. (1996). Malformed offspring, sibling matings, and selection against inbreeding in the sand lizard (Lacerta agilis). Journal of Evolutionary Biology 9: 229-242.

Pianka, E.R. \& Vitt, L.J. (2003). Lizards: Windows to the 
Evolution of Diversity. University of California Press, Berkeley, Los Angeles, London. 346 pp.

Quesnel, V.C. (1978). The reproductive behaviour of the lizard, Ameiva ameiva tobagana. Living World 19781979: 16-18.

Ribeiro, L.B., Gogliath, M., Sales, R.F.D.D. \& Freire, E.M.X. (2011). Mating behavior and female accompaniment in the whiptail lizard Cnemidophorus ocellifer (Squamata, Teiidae) in the Caatinga region of northeastern Brazil. Biota Neotropica 11: 363-368.

Rocha, C.F.D. (2008). Body size, female reproduction and sexual dimorphism in the lizard Ameiva ameiva (Teiidae) in a restinga of southeastern Brazil. Revista Brasileira de Zoologia 25: 370-372.

Sales, R.F.D. \& Freire, E.M.X. (2021). Reproductive behavior of Spix's Whiptails in the wild: understanding the costs and benefits of mate-guarding. Acta Ethologica 24: 41-51.

Uetz, P. (editor) The Reptile Database. http://www.reptiledatabase.org. Accessed 14th March 2021.

Vitt, L.J. (1982). Reproductive tactics of Ameiva ameiva (Lacertilia: Teiidae) in a seasonally fluctuating tropical habitat. Canadian Journal of Zoology 60: 3113-3120.
Vitt, L.J. (1983). Reproduction and sexual dimorphism in the tropical teiid lizard Cnemidophorus ocellifer. Copeia 1983: 359-366.

Vitt, L.J. (2003). Life versus sex: the ultimate choice. In Lizards: Windows To The Evolution of Diversity, 103 p. Pianka, E.R. \& Vitt, L.J. (Eds). University of California Press, Berkeley, Los Angeles, London.

Vitt, L.J. \& Colli, G.R. (1994). Geographical ecology of a Neotropical lizard: Ameiva ameiva (Teiidae) in Brazil. Canadian Journal of Zoology 72: 1986-2008.

Zaldívar-Rae, J. \& Drummond, H. (2007). Female accompaniment by male whiptail lizards: is it mate guarding? Behaviour 144: 1383-1402.

Zaldívar-Rae, J., Drummond, H., Ancona-Martínez, S., Manríquez-Morán, N.L. \& Méndez-De La Cruz, F.R. (2008). Seasonal breeding in the western Mexican whiptail lizard Aspidoscelis costata on Isla Isabel, Nayarit, Mexico. The Southwestern Naturalist 53: 175-184.

Accepted: 4 May 2021 